\title{
SOCIAL-ECONOMICS ANALYSIS AND COMMUNITY EMPOWERMENT THE WATERSHED OF KEDAUNG AT GAJAH MUNGKUR RESERVOIR WONOGIRI-CENTAL JAVA
}

\author{
Sarjiyanto ${ }^{1}$, Supriyadi², Arif Budi Nugroho ${ }^{3}$ \\ ${ }^{1}$ Faculty of Economy and Business, Universitas Sebelas Maret, 57126, \\ Surakarta, Indonesia \\ ${ }^{2}$ Faculty of Faculty of Agricultur, Universitas Sebelas Maret, 57126, Surakarta, Indonesia \\ ${ }^{3}$ Research and development office of wonogiri district, \\ E-mail: ${ }^{1}$ masyanto@staff.uns.ac.id, 2supriyadi_uns@yahoo.com, ${ }^{3}$ abun2025@gmail.com \\ Correspondence E-mail: masyanto@staff.uns.ac.id
}

Naskah Diterima: December 2016; Disetujui: February 2017

\begin{abstract}
Gajah Mungkur Reservoir is designed to storage reservoir for 100 years since the operation in 1982-2082. Currently the sedimentation rate reaches 8 millimeters per year, while the assumption of sediment rate (mud) is only 2 millimeters per year. This research was conducted to save reservoir and river basin environment in Gajah Mungkur Reservoir. This study aims to determine the socio-economic conditions and behavior of people in the Keduang River watershed area. This research also formulates community empowerment model in Keduang River area and recommends grand design management system involving various related parties.
\end{abstract}

Keywords: community empowerment, watershed areas

JEL Classification: F64, O20

Abstrak: Waduk Gajah Mungkur dirancang untuk menyimpan cadangan air selama 100 tahun sejak beroperasi pada tahun 1982-2082. Saat ini tingkat sedimentasi mencapai 8 milimeter per tahun, sedangkan asumsi laju sedimen (lumpur) hanya 2 milimeter per tahun. Penelitian ini dilakukan untuk menyelamatkan reservoir dan lingkungan Daerah Aliran Sungai di Waduk Gajah Mungkur. Penelitian ini bertujuan untuk mengetahui kondisi sosial ekonomi dan perilaku orang-orang di daerah DAS Keduang River. Penelitian ini juga merumuskan model pemberdayaan masyarakat di wilayah DAS Keduang River serta merekomendasikan grand design sistem manajemen yang melibatkan berbagai pihak yang terkait.

Kata kunci: pemberdayaan masyarakat, daerah aliran sungai

Klasifikasi JEL: F64, O20 


\section{INTRODUCTION}

The construction of reservoir in one region is one of the solution of problem exist in that region. The function of Gajah Mungkur reservoir located in Wonogiri Regency is to control flood, with water catchment area 1.350 $\mathrm{Km}^{2}$, Gajah Mungkur reservoir would be capable to control flood from $4000 \mathrm{~m}^{3} / \mathrm{s}$ to $400 \mathrm{~m}^{3} / \mathrm{s}$. This would secure all regions around Bengawan Solo stream, starts from Wonogiri, Ngawi, till to downstream in Gresik, East Java, and from flood is also functioned as irrigation, water supplier, and also electricity. The impact from the construction is the change of socio-economy of the people around the reservoir.

Economic success will cause change automatically in the economy structure of the people. In social perspective, the construction will cause the change of social structure where most of people will depend on their livelihood on fishery and tourism. Besides that impact, the positive impacts from the construction of the reservoir are absorption of labor and the increasing of people's income while the negative impact is pollution to environment, for example sedimentation is occurred faster than the previous estimation.

High sedimentation, especially sedimentation from 6 sub-region river stream which caused limited water storage capability. Gajah Mungkur reservoir is designed for 100 years, counted since the first operation in 1982 until 2082, with the maximum capability of sediment storage in the amount of 120 million $\mathrm{m} 3$ with the sediment rate assumption (mud sediment) 2 millimeters each year. But the fact now is the sedimentation rate reaches 8 millimeters each year. In this time, sediment that comes to Gajah Mungkur reservoir reaches 2.55 million $\mathrm{m}^{3}$ each year.

The negative and positive impact surely affects social and economy of the people so that needs the exact society empowerment model. Society empowerment is understood as the process or result (Laverack, 2001). Through empowerment process, the society would be capable to assume the ability to act effectively so it could change their life and neighborhood (Rich, 2009). The empowerment process promotes human resources participation, organization, and community to increase social life quality.

Society development has so many various definitions. It focused to the study of problem solving process simultaneously. The other definition of society development is to start social action so that it could change their economy, social, culture and environment situation (Mattessich, 2004). Empowerment theory contains two value orientations to practice and frame the concept to learn the society process and organization. Society empowerment is differing into psychology empowerment, organization empowerment, and society empowerment. Problem difference would affect the exact empowerment model in one region so that in this research could be known about the exact empowerment model in Sub watershed Keduang as the impact of Gajah Mungkur reservoir construction.

Based on the explanation above, there are research questions defined in order to reach the research purposes. Main output of this research is structured recommendation in the formulation of Wonogiri Regency Government policy to empower society around the river stream:

1. How is the social economy condition and society behavior around watershed of Keduang River Wonogiri?

2. How is the society empowerment model around watershed of Keduang River Wonogiri? 


\section{RESEARCH METHOD}

This study uses RRA (Rapid Rural Appraisal) and PRA (Participatory Rural Appraisal) method with consideration of efficiency, effectiveness and more importantly is aspirational in the sense of community involvement and community needs can be accommodated so that the expected model of empowerment in line with the needs of society).
Data collection is done on the documentation of studies that have been made by various parties, in-depth interviews with village officials, community leaders, farmers' groups, conservation groups, youth and aware group travel and also conducted field observations to compare data that obtained from interviews, documentation and questioner. Classification levels of vulnerability was presented on table in below :

Table 1. Classification levels of Social Economy and Institutional Vulnerability

\begin{tabular}{lll}
\hline Criteria & Score & Level Vulnerability \\
\hline High & $>4,3$ & Very Range \\
Rather High & $3,5-4,3$ & Range \\
Moderate & $2,6-3,4$ & Rather Range \\
Rather Low & $1,7-2,5$ & Slighty Range \\
Low & $<1,7$ & Not Range \\
\hline
\end{tabular}

Source: Paimin et al 2006

\section{RESULT AND DISCUSSION}

\section{a. Pondoksari Village}

Pondoksari Village, District of Nguntoronardi as sample areas that represent sub in downstream watershed of Keduang river. Pondoksari village is located in the northwestern town of Nguntoronadi district approximately $7 \mathrm{~km}$. Its area is 573 hectares, divided into 9 hamlets, 7 (CA) Citizens Association and 17 (NA) Neighborhood Association with an average altitude of 158 from the surface of the sea. The population in 2009 reached 2287 people with 1151 males and 1136 females.

Table 2. Analysis of Social Economy Institutional sub Downstream Watershed of Pondoksari

\begin{tabular}{clccc}
\hline \multirow{2}{*}{ Criteria } & \multicolumn{1}{c}{ Parameter/Integrity } & Integrity & Score & $\begin{array}{c}\text { Score } \mathbf{x} \\
\text { Integrity }\end{array}$ \\
\hline Social & Geographic population density & 10 & 3 & 30 \\
& Agrarian population density & 10 & 1 & 10 \\
& Conservation behavior & $\mathbf{2 0}$ & $\mathbf{3}$ & $\mathbf{6 0}$ \\
& Customary law & 5 & 5 & 25 \\
\multirow{5}{*}{ Economy } & Traditional value & 5 & 3 & 15 \\
& Dependence on land & 20 & 1 & 20 \\
& Income ratio & 10 & 2 & 20 \\
& Basic activity on region & $\mathbf{1 0}$ & 5 & 50 \\
& Institutional empowerment conservation & 5 & 5 & 25 \\
& Formal institutional empowerment in & 5 & 4 & 20 \\
& conservation & & & \\
\hline & Vunerability of Social, Economy and Institutional & & & 275 \\
\hline
\end{tabular}

Source: Primary Data, processed 2012 
Based on the results of the study was obtained that geographic population density has a score 3 , while scores in the agrarian population density 1 , whereas for conservation behaviors have a score 3. Customary law still have important role in the Pondoksari with a score 5 , while traditional values have a score 3 . Economically, state of residents base on dependence on land had a score 1 and an income ratio had a score 2. Based on the presence of institutional conservation and formal institutions empowerment on conservation scores respectively 5 and 4 .

\section{b. Sembukan Village}

Sembukan village, district of Sidoharjo was selected to represent sub middle watershed as research sample. Sembukan village approximately $8 \mathrm{~km}$ away from town of Sidoharjo district and the village that southernmost in Sidoharjo district. Its area is
$1272 \mathrm{ha}$, which is divided into 11 hamlets, 9 (CA) Citizens Association and 21 (NA) Neighborhood Association. The average elevation of this village approximately 355 from the surface of the sea. From the census of 2009 total population of 4239 people with 2194 males and 2045 womens.

Based on the results of the study was obtained that geographic population density has a score 3, while scores in the agrarian population density 1 , whereas for conservation behaviors have a score 3. Customary law still have important role in the Sembukan with a score 3 , while traditional values have a score 3 . Economically, state of residents base on dependence on land had a score 1 and an income ratio had a score 2. Based on the tpresence of institutional conservation and formal institutions empowerment on conservation scores respectively 1 and 3 .

Table 3. Analysis of Social Economy Institutional sub Middle Watershed of Sembukan

\begin{tabular}{lllll}
\hline Criteria & Parameter/Integrity & Integrity Score & $\begin{array}{l}\text { Score } \mathbf{x} \\
\text { Integrity }\end{array}$ \\
\hline Social & Geographic population density & 10 & 3 & 30 \\
& Agrarian population density & 10 & 1 & 10 \\
& Conservation behavior & 20 & 3 & 60 \\
& Customary law & 5 & 3 & 15 \\
& Traditional value & 5 & 3 & 15 \\
Economy & Dependence on land & 20 & 1 & 20 \\
& Income ratio & 10 & 2 & 20 \\
& Basic activity on region & 10 & 1 & 10 \\
& Institutionational empowerment conservation & 5 & 1 & 5 \\
& Formal institutional empowerment in conservation & 5 & 3 & 15 \\
\hline & Vunerability of Social, Economy and Institutional & & & $\mathbf{2 0 0}$ \\
\hline
\end{tabular}

Source: Primary Data, processed 2012

\section{c. Padarangin village}

Padarangin village, district of Slogohimo was selected to represent sub upstream watershed as research sample. Padarangin village approximately $7.8 \mathrm{~km}$ away from town of Slogohimo district. Its area is 799 ha, which is divided into 5 hamlets, 7 (CA) Citizens Association and 21 (NA) Neighborhood Association. The average elevation of this village up 628 from the surface of the sea. From the census of 2009 total population of 3426 people with 1687 males and 1739 womens. 
Table 4. Analysis of Social Economy Institutional Sub Upstream Watershed of Pandarangin

\begin{tabular}{llccc}
\hline \multirow{2}{*}{ Criteria } & \multicolumn{1}{c}{ Parameter/Integrity } & Integrity & Score & $\begin{array}{c}\text { Score } \mathbf{x} \\
\text { Integrity }\end{array}$ \\
\hline Social & Geographic population density & $\mathbf{1 0}$ & $\mathbf{5}$ & $\mathbf{5 0}$ \\
& Agrarian population density & $\mathbf{1 0}$ & $\mathbf{5}$ & $\mathbf{5 0}$ \\
& Conservation behavior & 20 & 1 & 20 \\
& Customary law & 5 & 3 & 15 \\
& Traditional value & 5 & 1 & 5 \\
Economy & 20 & 1 & 20 \\
& Dependence on land & 10 & 4 & 40 \\
& Income ratio & $\mathbf{1 0}$ & $\mathbf{5}$ & $\mathbf{5 0}$ \\
Basic activity on region & 5 & 5 & 25 \\
& Institutional Institutional empowerment conservation & 3 & 15 \\
\hline & Formal institutional empowerment in conservation & 5 & & $\mathbf{2 9 0}$ \\
\hline & Vunerability of Social, Economy and Institutional & & &
\end{tabular}

Based on the results of the study was obtained that geographic population density has a score 5, while scores in the agrarian population density 5 , whereas for conservation behaviors have a score 1 . Customary law still have important role in the Padarangin with a score 3, while traditional values have a score 1 . Economically, state of residents base on dependence on land had a score 1 and an income ratio had a score 4 . Based on the presence of institutional conservation and formal institutions empowerment on conservation scores respectively 5 and 3 .

\section{d. Semin Village}

Semin village, district of Nguntoronadi was selected to represent micro sub watershed at south as research sample. Semin village is located at east from town of Nguntoronadi district with distance approximately $7,8 \mathrm{~km}$. Its area is $726 \mathrm{ha}$, which is divided into 7 hamlets, 7 (CA) Citizens Association and 16 (NA) Neighborhood Association. The average elevation of this village up 628 from the surface of the sea. From the census of 2009 total population of 3121 people with 1552 males and 1569 womens.

Table 5. Analysis of Social Economy Institutional Micro sub Watershed at South Side (Semin Village)

\begin{tabular}{llccc}
\hline \multicolumn{1}{c}{ Criteria } & \multicolumn{1}{c}{ Parameter/Integrity } & Integrity & Score & $\begin{array}{c}\text { Score } \mathbf{x} \\
\text { Integrity }\end{array}$ \\
\hline Social & Geographic population density & $\mathbf{1 0}$ & $\mathbf{5}$ & $\mathbf{5 0}$ \\
& Agrarian population density & 10 & 1 & 10 \\
& Conservation behavior & 20 & 2 & 40 \\
& Customary law & 5 & 3 & 15 \\
\multirow{5}{*}{ Economy } & Traditional value & 5 & 3 & 15 \\
& Dependence on land & 20 & 1 & 20 \\
& Income ratio & 10 & 2 & 20 \\
\multirow{5}{*}{ Institutional } & $\mathbf{1 0}$ & 5 & $\mathbf{5 0}$ \\
& Basic activity on region & 5 & 5 & 25 \\
& Institutional empowerment conservation & 5 & 15 \\
\hline & Formal institutional empowerment in conservation & 5 & & $\mathbf{2 6 0}$ \\
\hline
\end{tabular}

Source: Primy Data, processed 2012 
Based on the results of the study was obtained that geographic population density has a score 5, while scores in the agrarian population density 1 , whereas for conservation behaviors have a score 2. Customary law still have important role in the Semin with a score 3, while traditional values have a score 3 . Economically, state of residents from dependence on land had a score 1 and an income ratio had a score 2. Based on the presence of institutional conservation and formal institutions empowerment on conservation scores respectively 5 and 3 .

\section{e. Semagar Village}

Semagar village, district of Girimarto as selected to represent micro sub watershed at west of north region as research sample. Semagar village is located at east from town of Girimarto district with distance approximately $5 \mathrm{~km}$ away. Its area is $498.77 \mathrm{ha}$, which is divided into 8 hamlets, 8 (CA) Citizens Association and 19 (NA) Neighborhood Association. The average elevation of this village approximately $600 \mathrm{~m}$ from the surface of the sea. From the census of 2009 total population of 3591 people with 1818 males and 1773 womens.

Table 6. Analysis of Social Economy Institutional Micro sub Watershed at West On North Region (Semagar village)

\begin{tabular}{lllll}
\hline Criteria & Parameter/Integrity & Integrity Score & $\begin{array}{l}\text { Score } \mathbf{x} \\
\text { Integrity }\end{array}$ \\
\hline Social & Geographic population density & $\mathbf{1 0}$ & $\mathbf{5}$ & $\mathbf{5 0}$ \\
& Agrarian population density & 10 & 1 & 10 \\
& Conservation behavior & 20 & 2 & 40 \\
& Customary law & 5 & 2 & 10 \\
& Traditional value & 5 & 1 & 5 \\
Economy & Dependence on land & 20 & 1 & 20 \\
& Income ratio & 10 & 3 & 30 \\
& Basic activity on region & $\mathbf{1 0}$ & $\mathbf{5}$ & $\mathbf{5 0}$ \\
\multirow{5}{*}{ Institutional } & Institutional empowerment conservation & 5 & 1 & 5 \\
& Formal institutional empowerment in conservation5 & 3 & 15 \\
\hline & Vunerability of Social, Economy and Institutional & & $\mathbf{2 3 5}$ \\
\hline
\end{tabular}

Source: Primary Data, processed 2012

Based on the results of the study was obtained that geographic population density has a score 5, while scores in the agrarian population density 1 , whereas for conservation behaviors have a score 2. Customary law still have important role in the Semagar with a score 2 , while traditional values have a score 1 . Economically, state of residents base on dependence on land had a score 1 and an income ratio had a score 3 . Based on the presence of institutional conservation and formal institutions empowerment on conservation scores respectively 1 and 3 .

\section{f. Setren village}

Setren village, district of Slogohimo as selected to represent micro sub watershed at east of north region as research sample. Setren village is located at north from town of Slogohimo district with distance approximately $7,1 \mathrm{~km}$ away. Its area is $990,8 \mathrm{ha}$, which is divided into 4 hamlets, 8 (CA) Citizens Association and 19 (NA) Neighborhood Association. The average elevation of this village up to $884 \mathrm{~m}$ from the surface of the sea. From the census of 2009 total population of 3142 people with 1570 males and 1572 womens. 
Table 7. Analysis of Social Economy Institutional Micro Sub Watershed at East On North Region (Setren Village)

\begin{tabular}{lllll}
\hline Criteria & Parameter/Integrity & Integrity & Score & $\begin{array}{l}\text { Score } \\
\text { Integrity }\end{array}$ \\
\hline Social & Geographic population density & 10 & 3 & 30 \\
& Agrarian population density & 10 & 1 & 10 \\
& Conservation behavior & 20 & 1 & 20 \\
& Customary law & 5 & 2 & 10 \\
\multirow{5}{*}{ Economy } & Traditional value & 5 & 1 & 5 \\
& Dependence on land & $\mathbf{2 0}$ & $\mathbf{3}$ & $\mathbf{6 0}$ \\
& Income ratio & 10 & 4 & 40 \\
& Basic activity on region & $\mathbf{1 0}$ & 5 & $\mathbf{5 0}$ \\
& Institutional empowerment conservation & 5 & 1 & 5 \\
& Formal institutional empowerment in conservation & 5 & 1 & 5 \\
\hline
\end{tabular}

Source: Primary Data, processed 2012

Based on the results of the study was obtained that geographic population density has a score 3 , while scores in the agrarian population density 1 , whereas for conservation behaviors have a score 1 . Customary law still have important role in the Setren with a score 2, while traditional values have a score 1 . Economically, state of residents base on dependence on land had a score 3 and an income ratio had score 4 . Based on the presence of institutional conservation and formal institutions empowerment on conservation scores 1.

\section{Empowerment Model}

Empowerment model at each sub watershed was based on scoring of social, economy and institutional analysis. Empowerment refered to decrease vulnerability on parameter from each criteria that have highest vulnerability value, then it connected with comunity needs that was resulted from interview and observation at field. Hopefully, that model can be done and accepted by comunity. Because empowerment principle is an effort to achieve community needs, so "stranger" doesn't have a role as a instructor or builder but have the role as facilitators that be in charge to facilitate, push and ease community in order to empowerment themself. So that facilitators only facilitate in terms of problem analysis, organization assist and advocation of rules.

Table 8. Models of Empowerment in Watershed Kedaung that Priorited on Resident Management and Basic Activity on Region

\begin{tabular}{|c|c|c|}
\hline CRITERIA & ACTIVITY & FACILITATORS \\
\hline \multirow[t]{6}{*}{ Social Economy } & Improvement of tourism village/village charm & Depart. of Tourism \\
\hline & Training of farmer on agrotourism & Depart. of Agriculture \\
\hline & Management of daity cattle/ etawa goat & Depart. of Agriculture \\
\hline & $\begin{array}{l}\text { Management of livestock and animal waste } \\
\text { (biogas, manure) }\end{array}$ & Environmental agency \\
\hline & Empowerment of integrated farming system & Depart. of Agriculture \\
\hline & $\begin{array}{l}\text { Management agricultural product/livestock to } \\
\text { support tourism village (typical souvenirs from }\end{array}$ & Empowerment Board villagers \\
\hline
\end{tabular}




\begin{tabular}{|c|c|c|}
\hline CRITERIA & ACTIVITY & FACILITATOR \\
\hline & Setren) & \\
\hline & Training of local tradition & Depart. of Tourism \\
\hline & $\begin{array}{l}\text { Training of souvenirs making (puppet, tradition } \\
\text { local) }\end{array}$ & Department of Trade \\
\hline & Improvement of tourism market & Depart. of cooperative \\
\hline & $\begin{array}{l}\text { Training of conservation technic (land } \\
\text { management, breeding) }\end{array}$ & Estate agency \\
\hline \multirow{6}{*}{$\begin{array}{l}\text { Regulation } \\
\text { Institutional }\end{array}$} & $\begin{array}{l}\text { Cultivation on } \\
\text { forest/garden/horticultura with basic of } \\
\text { improvement tourism (durian, coffee beans, } \\
\text { avocado,cacao,snakefruit, vegetables) }\end{array}$ & Depart. of Agriculture \\
\hline & Cultivation of fishing pond & Fisheries department \\
\hline & $\begin{array}{l}\text { Empowerment of farmer group/ training of } \\
\text { tourism farmer }\end{array}$ & Empowerment Board \\
\hline & Empowermnet of Farmers Community & Local Goverment \\
\hline & $\begin{array}{l}\text { Reinforcement of cooperation in community } \\
\text { (managemnet training) }\end{array}$ & Depart. of cooperative \\
\hline & Organizing of conservation village device & Farmers Community \\
\hline
\end{tabular}

\section{CONCLUSION AND RECOMMENDATIONS}

\section{Conclusion}

The result from analysis of vulnerability levels on social, economy and institutional was obtained score to each sample region, as follows:

a) Pondoksari village score 275 in the category moderate with vulnerability level is slightly susceptible, the highest vulnerability value on activity of conservation and region basic activity.

b) Sembukan village score 200 in the category slightly low with vulnerability level is slightly susceptible, the highest vulnerability value on activity of conservation and geographic population density.

c) Padarangin village score 290 in the category moderate with vulnerability level is slightly susceptible, the highest vulnerability value on geographic population density, agrarian population denstiy and region basic activity.

d) Semin village score 260 in the category moderate with vulnerability level is slightly susceptible, the highest vulnerability value on geographic population density and region basic activity.

e) Semagar village score 235 in the category slightly low with vulnerability level is slightly susceptible, the highest vulnerability value on geographic population density and region basic activity.

f) Setren village score 235 in the category slightly low with vulnerability level is slightly susceptible, the highest vulnerability value on land dependence and region basic activity.

Empowerment model for each region can't be generalized although vulnerability value with the same score and same parameter. That model can be more focus on community needs and resources available, so that goverment in this case Work area unit of Wonogiri local government and relevant agency sincerely can be as facilitators in order to analize problems, assist on organizing and advocation of rule. 


\section{Recommendation}

a. Watershed management implementation must always associate with accessibility conditions that exist in society. The more open society conditions will be different with a more closed society.

b. Improvement income can be done with earn income outside agriculture, especially livestock, trading, agroindustry and activity that basic on resources on watershed region.

c. Model of participate natural resources conservation can be done according to the stage where an understanding of conservation socialized well, especially in the coordination group given the authority to coordinate the relevant stakeholders that support conservation activities. In addition, needed the individual commitment of the decision makers on-site conservation activities. Therefore, coordination and socialization understanding of the importance of conservation with related agencies should be conducted continuously through a variety of formal and informal meetings without any limitation of quantity meeting.

d. Need to be arranged grand design Keduang watershed management that it is linking various stakeholders. Grand design that really targeted and sustainable is in effort to collaborate the work program which is owned by each work area unit of Wonogiri local government so that Keduang community development and conservation and watershed management will not overlap in TUPOKSI and programs.

\section{REFERENCES}

Bappeda dan BPS Kabupaten Wonogiri, 2010

"Wonogiri Dalam Angka Tanun 2010".

Bappeda dan BPS Kabupaten Wonogiri, 2010,

"Kecamatan Girimarto Dalam Angka Tahun 2009".
Bappeda dan BPS Kabupaten Wonogiri, 2010, "Kecamatan Nguntoronadi Dalam Angka Tahun 2009".

Bappeda dan BPS Kabupaten Wonogiri, 2010, "Kecamatan Sidoharjo Dalam Angka Tahun 2009".

Bappeda dan BPS Kabupaten Wonogiri, 2010, "Kecamatan Slogohimo Dalam Angka Tahun 2009".

Bappeda dan BPS Kabupaten Wonogiri, 2010, "PDRB Kabupaten Wonogiri Tahun 2009".

Bappeda Kabupaten Wonogiri, 2010, “Data dan Analisis Rencana Tata Ruang Wilayah (RTRW) Kabupaten Wonogiri Tahun 2010-2030".

Bappeda Kabupaten Wonogiri, 2010, “Laporan Kegiatan Penunjang Penyusunan dan Pengembangan Profil Daerah Kabupaten Wonogiri Tahun 2009".

Dewi R Indrawati, Purwanto, dan Paimin, 2009 “Formulasi Kerentanan Sosial Ekonomi dan Kelembagan sebagai Diagnosis Degradasi Lahan".

Laverack, G.; Wallerstein, N. 2001. Measuring community empowerment: a fresh look at organizational domains. Health Promot. Int.

Mattessich, P. and Monsey, M. 2004. Community Building: What Makes It Work, St. Paul. MN: Wilder Foundation.

Rich, M.J.; Stoker, R.P. 2009. Rethinking empowerment: Local empowerment zone programs. Urb. Aff. Rev. 